\title{
Studi Empiris Kekuatan Stabilitas Keuangan Perbankan Syariah di Indonesia
}

\author{
Elok Heniwati* \\ Fakultas Ekonomi dan Bisnis, Universitas Tanjungpura, Indonesia
}

\begin{abstract}
The study aims to examine the stability of Islamic banking in Indonesia after the global financial crisis. This study is significant, considering the rapidly growth of Islamic banking in Indonesia and uniqueness of its operating systems and products. By using secondary data from the annual reports of the banking sector listed on the Indonesia Stock Exchange (IDX) for the period from 2013 to 2016, regression analysis with the ZSCORE function (insolvency risk) as the dependent variable and a number of predictor variables (firm-specific, macroeconomic and governance) are used as tools for achieving research objectives. To check the robustness of the research findings, a model with different specifications has been used. The results indicate that profitability and firm size have a significant influence on the insolvency risk (ZSCORE) of banks and empirical factors that influence these risks differ between Islamic banks and conventional banks.
\end{abstract}

JEL : G01; G21; G30

Keywords : ZSCORE, Islamic banking, financial stability, insolvency risk

\section{PENDAHULUAN}

Kondisi perekonomian dan keuangan syariah Indonesia di tahun 2017 secara umum menunjukkan perbaikan pertumbuhan, kinerja yang stabil dengan struktur yang lebih berimbang. Hal ini terlihat dari angka pertumbuhan Produk Domestik Bruto (PDB) Riil dalam 3 tahun terakhir menunjukkan tren yang stabil dan mengalami peningkatan dari 5,03\% menjadi sebesar $5,07 \%$, angka inflasi yang terjaga pada kisaran $3 \pm 1 \%$ dan nilai tukar rupiah yang stabil yang berada pada rentang Rp13.323 - Rp13.563 per USD pada akhir tahun 2017. Di sektor perbankan syariah sendiri, meskipun mengalami perlambatan dibandingkan tahun sebelumnya, namun pertumbuhan aset, pembiayaan yang disalurkan (PYD), dan dana pihak ketiga (DPK) masih terjaga angka yang cukup tinggi (dua digit), yaitu masing-masing sebesar adalah 18,97\%, 15,24\% dan 19,83\% (yoy). Perbaikan kinerja tersebut antara lain dipengaruhi oleh kondisi perekonomian nasional yang stabil dan berdampak kepada perbaikan kinerja Indeks Jasa Keuangan (IJK) Syariah. Selain perbaikan kinerja keuangan, capaian juga dapat dilihat dengan adanya keberagaman produk dan aktivitas, kelengkapan kerangka hukum dan peraturan, dan meningkatnya jumlah pelaku yang turut melakukan kegiatan usaha di industri keuangan syariah (OJK, 2017, hlm. v-vi).

*Email : elok.heniwati@ekonomi.untan.ac.id Received : 24-09-2018, Accepted: 06-11-2018, Published : 29-08-2019

P-ISSN : 2087-9954, E-ISSN : 2550-0066. DOI : http://dx.doi.org/10.26418/jebik.v8i2.28015 
Meningkatnya peran industri syariah secara global maupun nasional telah mendorong para peneliti untuk mengkaji stabilitas keuangan industri, termasuk perbankan syariah. Mereka melakukan kajian tentang stabilitas di sejumlah negara seperti Pakistan (Shahid, 2012; Rashid, Yousaf and Khaleequzzaman, 2017), negara-negara MENA dan Asia Selatan (Rajhi and Hassairi, 2013), Saudi Arabia (Ghassan, Fachin and Guendouz, 2013), dan negara-negara Eropa Tengah dan Timur (Ivičić, Kunovac, \& Ljuba, 2008). Pengamatan atas penelitian tersebut menunjukkan bahwa sejumlah prediktor seperti karakteristik khusus bank (ROA, ROE, ukuran bank, rasio BOPO dan hutang terhadap aset), makro ekonomi (inflasi, GDP), dan governance (indeks) berpengaruh relatif terhadap stabilitas keuangan atau tingkat risiko individual bank. Sejumlah peneliti berpendapat bahwa alat analisis yang paling populer dan powerful untuk mengukur risiko individual bank adalah ZSCORE (Uhde and Heimeshoff, 2009; Ahmed, 2010; Čihák and Hesse, 2010; Goaied and Sassi, 2011; Shahid, 2012; Rahim and Zakaria, 2013; Husein, 2014; Farooq and Zaheer, 2015; Odeduntan, Adewale and Hamisu, 2016; Ghassan and Krichene, 2017; Rashid, Yousaf and Khaleequzzaman, 2017).

Di Indonesia, penelitian tentang stabilitas keuangan bank syariah telah dilakukan oleh (Rokhim and Gamaginta, 2011) yang menganalisis stabilitas keuangan 12 bank syariah dan 71 bank konvensional selama periode 2004-2009. Dengan menggunakan ZSCORE sebagai ukuran kesehatan bank, mereka menemukan bahwa ada perbedaan yang signifikan antara bank syariah dengan bank konvensional terkait dengan istilah stabilitas keuangan. Bank Islam kecil memiliki level stabilitas yang hampir sama dengan stabilitas bank kecil konvensional. Sedang full-fledged Islamic banks memiliki ZSCORE yang rendah dibandingkan dengan unit bisnis Islam. Secara umum stabilitas keuangan bank syariah lebih rendah dibandingkan dengan stabilitas keuangan bank konvensional.

Sejalan dengan penelitian sebelumnya, penelitian ini juga menggunakan ZSCORE sebagai fungsi dari sejumlah variabel kinerja operasi, makro ekonomi dan governance untuk mengevaluasi kekuatan stabilitas perbankan syariah di Indonesia. Hal ini dipicu oleh fakta bahwa pertumbuhan bank syariah di Indonesia yang semakin pesat serta adanya keunikan sistem operasional dan produk yang dimiliki. Oleh karena itu, evaluasi atas stabilitas keuangan perbankan syariah menjadi penting untuk dilakukan karena akan berimbas pada kesehatan sistem keuangan nasional. Mengacu pada penelitian Rashid, Yousaf and Khaleequzzaman (2017) dan Čihák and Hesse (2010), penelitian ini dimaksudkan untuk menjawab pertanyaan: Bagaimana kontribusi stabilitas bank syariah dan bank konvensional terhadap stabilitas keuangan industri keuangan di Indonesia?

Hasil dari studi berguna dalam membantu meningkatkan pemahaman tentang faktorfaktor yang mempengaruhi stabilitas keuangan sistem perbankan. Selain itu, hasil studi juga memperdalam pengetahuan tentang peran bank syariah dan konvensional bagi stabilitas keuangan.

\section{KAJIAN LITERATUR}

\section{Bank Syariah dalam Perspektif Prudential}

Keterikatan pada hukum syariah yang melarang perikatan berbasis bunga merupakan karakteristik dasar dari bank syariah. Sebagai gantinya, bank menggunakan sistem bagi hasil (profit-loss sharing/PLS), pembelian atau penjualan barang dan jasa, dan tarif provisi jasa 
sebagai dasar perikatan. Pada sistem PLS, tarif pengembalian aset keuangan tidak diketahui atau ditetapkan sebelum transaksi dilaksanakan. Pada transaksi pembelian dan penjualan barang/jasa, nilai mark-up ditentukan berdasarkan benchmark tertentu, yang biasanya oleh pasar internasional seperti LIBOR. Dalam hukum syariah, perikatan yang timbul akan tergantung pada hak-hak investor di proyek tersebut dan timing arus kas. Sedang karakteristik yang lain adalah melarang perdagangan pada produk-produk yang bersifat spekulatif (gharar atau gambling) serta mendanai kegiatan yang dianggap haram (Čihák and Hesse, 2010).

Atas dasar karakteristik operasional tersebut, bank syariah menghadapi risiko yang unik dibandingkan dengan risiko yang dihadapi oleh bank konvensional. Keunikan itu timbul dari sifat dasar kontrak syariah serta seluruh hukum, tata kelola (governance) dan likuiditas infrastruktur dari keuangan syariah (Čihák and Hesse, 2010). Menurut Sundararajan and Errico (2002), saat menilai stabilitas sistem keuangan bank syariah, berbagai risiko yang melekat akibat karakteristik spesifik bank syariah harus dipertimbangkan. Mereka beranggapan bahwa karakteristik itu mungkin dipengaruhi oleh daya saing dan ketahanan terhadap kejutan eksternal yang berpotensi memberi dampak sistemik. Lebih lanjut mereka menyatakan bahwa pengelolaan atas keunikan risiko sektor perbankan syariah dapat diatasi melalui kecukupan modal dan cadangan, penilaian dan pengendalian risiko yang tepat, aturan dan praktik governance, pengungkapan, akuntansi dan auditing yang kuat, dan infrastruktur yang memfasilitasi manajemen likuiditas.

Menurut Čihák and Hesse (2010), dampak dari keunikan risiko tersebut, bank syariah memiliki daya tahan lebih dibandingkan dengan bank konvensional. Misalnya, bank syariah dapat mengalihkan kejutan negatif di sisi aset (seperti kerugian Musharaka) ke depositor investasi (pada skema Mudaraba), dimana ini akan memberi perlindungan tambahan bagi bank. Bank syariah juga lebih konservatif. Keharusan menyediakan return yang stabil dan kompetitif, akses likuiditas yang lebih sulit, dan pembebanan tanggungjawab kepada investor atas kelalaian atau kesalahan diasumsikan dapat mengurangi terjadinya moral hazard dan risk taking. Adanya pengalihan risiko juga telah mendorong adanya peningkatan pengawasan oleh investor. Demikian juga dengan komposisi aset yang tinggi (aturan pembentukan cadangan tinggi) juga menyebabkan stabilitas bank syariah lebih baik dibandingkan dengan stabilitas bank konvensional.

\section{Faktor-faktor yang mempengaruhi stabilitas keuangan}

Sampai saat ini belum ada definisi baku dari stabilitas keuangan yang diterima secara internasional. Oleh karena itu, muncul beberapa definisi yang pada intinya mengatakan bahwa suatu sitem keuangan memasuki tahap tidak stabil pada saat sistem tersebut telah membahayakan dan menghambat kegiatan ekonomi. Lebih lanjut, Bank Indonesia menyebutkan bahwa arti stabilitas sistem keuangan dapat dipahami dengan melakukan penelitian terhadap faktor-faktor yang dapat menyebabkan instabilitas di sektor keuangan yang dapat dipicu oleh berbagai macam penyebab dan gejolak yang pada intinya merupakan kombinasi antara kegagalan pasar, baik karena faktor struktural maupun perilaku. Kegagalan pasar dapat bersumber dari eksternal (internasional) dan internal (domestik). Risiko yang sering menyertai kegiatan dalam sistem keuangan seperti risiko likuiditas, risiko pasar dan risiko operasional (www.bi.go.id).

\subsection{Pengaruh karakteristik individual bank terhadap stabilitas keuangan bank syariah}

Sejumlah variabel karakteristik individual bank seperti profitabilitas, income diversity, efisiensi biaya, komposisi aset, dan ukuran bank telah digunakan untuk menguji stabilitas 
keuangan bank (Čihák and Hesse, 2010; Rashid, Yousaf and Khaleequzzaman, 2017). Hasil penelitian mereka menunjukkan bahwa profitabilitas, income diversity, dan ukuran bank berpengaruh positif terhadap stabilitas keuangan. Penelitian ini menggunakan proksi ROE untuk mengukur profitabilitas bank. ROE menunjukkan tingkat efisiensi pengelolaan ekuitas dalam menghasilkan laba sehingga diasumsikan bahwa semakin tinggi rasio probabilitas, semakin rendah insolvabilitas bank. Asumsi yang sama juga digunakan untuk interpretasi variabel ukuran perusahaan. Income diversity menggambarkan keragaman pendapatan bank, yaitu sampai sejauh mana keragaman pendapatan bank dari aktivitas utama memperoleh bunga (bagi hasil untuk bank syariah) ke aktivitas lain. Semakin tinggi rasio income diversity, semakin rendah insolvabilitas. Dengan demikian hipotesis yang diajukan adalah: ROE, ukuran bank, dan income diversity berpengaruh positif terhadap stabilitas keuangan bank.

Komposisi aset diukur berdasarkan rasio hutang atas aset (HuAs). Rasio ini mengukur likuiditas, yang menilai porsi aset yang didanai dengan menggunakan hutang atau banyaknya aktiva yang dijaminkan untuk memperoleh hutang. Semakin tinggi rasio ini, semakin banyak aset yang dijaminkan ke investor sehingga semakin rendah stabilitas bank. Sedang efisiensi biaya diukur berdasarkan rasio biaya atas pendapatan (BOPO). Rasio ini menunjukkan kemampuan bank dalam mengelola beban operasional untuk menghasilkan pendapatan operasional. Implikasinya, semakin besar rasio ini, semakin tidak efisien manajemen bank tersebut dalam mengelola beban operasionalnya. Dengan demikian dapat disimpulkan bahwa semakin tinggi rasio HuAs dan BOPO, semakin tinggi risiko insolvabilitas bank. Dengan demikian hipotesis yang diajukan adalah: Rasio HuAs dan BOPO berpengaruh negatif terhadap stabilitas keuangan bank.

\subsection{Pengaruh makro ekonomi terhadap stabilitas keuangan bank syariah}

Pertumbuhan bank dapat dipengaruhi oleh kondisi makro ekonomi seperti inflasi dan GDP. Meningkatnya harga-harga secara umum dan terjadi secara terus menerus sering disebut dengan inflasi. Inflasi berdampak pada terjadinya penurunan daya beli masyarakat karena tingkat pendapatan riilnya juga menurun. Bagi industri perbankan, keadaan tersebut dapat berimbas langsung pada perannya sebagai lembaga intermediasi yang menjalankan sirkulasi dana di masyarakat. Inflasi dapat mengganggu fungsi kerja uang, menyebabkan masyarakat enggan menabung, menarik dananya di bank dan gangguan-gangguan lain yang pada akhirnya berdampak pada sistem ketahanan keuangan bank. Sedangkan GDP adalah jumlah barang dan jasa yang diproduksi dalam satu tahun oleh suatu negara. GDP riil dianggap sebagai ukuran luas untuk menggambarkan kemakmuran ekonomi. Semakin tinggi angka kemakmuran, semakin baik ia dalam mendukung stabilitas sistem keuangan. Kegairahan ekonomi akan berdampak pada meningkatnya daya beli dan keinginan untuk menyimpan dana sehingga berdampak positif pada stabilitas bank.

Temuan Rashid, Yousaf and Khaleequzzaman (2017) dan Čihák and Hesse (2010) saat menguji stabilitas bank menunjukkan bahwa kedua variabel makro yang diwakili GDP dan inflasi berpengaruh pada stabilitas keuangan bank. Hasil ini didukung oleh penelitian Beck, Demirgüç-Kunt and Merrouche (2010). Atas dasar hal tersebut, hipotesis yang diajukan adalah: Inflasi berpengaruh secara negatif dan GDP berpengaruh secara positif terhadap stabilitas keuangan bank. 


\subsection{Pengaruh governance terhadap stabilitas keuangan}

Meskipun belum ada konsensus tunggal tentang definisi corporate governance, namun sejumlah teori menyatakan bahwa corporate governance yang lemah dapat mengikis stabilitas keuangan melalui peningkatan kerentanan terhadap kejutan-kejutan eksternal. Kaufmann, Kraay and Mastruzzi (2007) mendefnisikan governance sebagai perkembangan institusional suatu negara yang mungkin berdampak pada risiko bank yang diukur berdasarkan enam dimensi yaitu berpendapat dan akuntabilitas, kualitas regulasi, stabilitas politik, efektifitas pemerintah, aturan hukum dan kendali atas korupsi. Keenam dimensi tersebut dikompilasi dalam suatu indeks governance.

Čihák and Hesse (2010) menggunakan variabel indeks governance tersebut sebagai prediktor stabilitas keuangan bank. Hasil studi menunjukkan bahwa variabel governance berdampak secara positif dan signifikan terhadap stabilitas keuangan bank. Hal ini mengindikasikan bahwa governance yang baik secara umum akan berkorelasi dengan tingginya nilai ZSCORE. Berdasarkan pada penjelasan tersebut, hipotesis yang diajukan adalah: Governance berpengaruh positif terhadap stabilitas keuangan bank.

\section{METODA PENELITIAN}

\subsection{Data dan Pengumpulan Data}

Penelitian ini menggunakan data yang dikumpulkan dari beberapa sumber. Data karakteristik perusahaan dikumpulkan dari laporan keuangan yang diterbitkan oleh sampel penelitian (www.idx.go.id). Data makro ekonomi diperoleh dari Badan Pusat Statistik/BPS (www.bps.go.id) dan data governance diperoleh dari the worldwide governance indicators (WGIdataset.xlsx). Data yang dikumpulkan adalah data tahunan yang mencakup periode empat tahun (2013-2016).

\subsection{Variabel dan Pengukurannya \\ Variabel dependen}

Sejumlah studi telah menggunakan ZSCORE sebagai ukuran solvabilitas, risiko, dan kesehatan keuangan bank. Penelitian ini menggunakan ZSCORE yang berfungsi sebagai ukuran risiko individual bank sebagai variabel dependen. Menurut asumsi distribusi pengembalian normal, fungsi ZSCORE mengukur risiko melalui jumlah standar deviasi yang harus dipenuhi di mana ekuitas dan probabilitas tidak cukup mengimbangi kerugian. Dengan demikian ZSCORE akan berbanding terbalik dengan probabilitas kebangkrutan bank Nilai ZSCORE yang lebih tinggi akan berada di batas atas risiko insolvabilitas, sehingga nilai yang tinggi berarti memiliki probabilitas insolvabilitas yang rendah dan sebaliknya (Uhde and Heimeshoff, 2009; Čihák and Hesse, 2010; Shahid, 2012; Rashid, Yousaf and Khaleequzzaman, 2017). ZSCORE dikalkulasi dengan cara:

$$
Z_{-} \text {score }=\frac{\frac{E Q}{A}+\mu_{R O A}}{\sigma_{R O A}}
$$

Persamaan (1)

dimana $\mathrm{EQ} / \mathrm{A}$ adalah ekuitas modal yang diukur sebagai persentase dari total aset, $\mu_{R O A}$ adalah rata-rata tingkat pengembalian aset (ROA), dan $\sigma_{R O A}$ adalah standar deviasi pengembalian aset yang merupakan proksi dari volatilitas pengembalian.

Menurut Čihák and Hesse (2010), sistem metrik tersebut dapat diterapkan pada risiko bank syariah karena ia merupakan alat ukur yang objektif, yang fokus pada risiko insolvabilitas, 
yaitu risiko bahwa modal dan cadangan bank (konvensional, syariah atau lainnya) mengalami penyusutan. ZSCORE berlaku sama untuk bank yang menggunakan strategi risiko tinggi/pengembalian tinggi dan bank yang menggunakan strategi risiko rendah/pengembalian rendah, karena strategi tersebut mengarah pada pengembalian yang disesuaikan dengan risiko (risk-adjusted returns) yang sama. Jika institusi memilih untuk memiliki risk-adjusted returns yang rendah, ia masih dapat memiliki ZSCORE yang sama atau lebih tinggi asalkan ia memiliki kapitalisasi yang lebih tinggi. Dalam hal ini, ZSCORE memberi ukuran yang objektif atas kesehatan keuangan.

\section{Variabel independen}

Variabel independen dalam penelitian ini meliputi struktur pendapatan, rasio hutang terhadap aset (HuAs), profitabilitas, BOPO dan ukuran bank.

\section{Variabel kontrol}

Variabel kontrol dalam penelitian ini adalah laju pertumbuhan PDB, inflasi dan governance. Deskripsi dan pengukuran masing-masing variabel dijelaskan di Tabel 1.

\subsection{Metode Analisis}

\section{Statistik Deskriptif dan Asumsi Klasik}

Statistik deskriptif digunakan untuk memberikan deskripsi atas data penelitian yang disajikan atas dasar nilai maksimum, minimum, rata-rata, dan standar deviasi. Untuk memenuhi persyaratan uji regresi, sejumlah uji asumsi klasik seperti uji normalitas, autokorelasi, heteroskedastisitas dan multikolinearitas telah dilakukan. Hasilnya menunjukkan bahwa data telah memenuhi syarat untuk uji hipotesis.

\section{Model Regresi}

Tujuan utama dari penelitian adalah untuk menguji apakah bank syariah lebih stabil atau kurang stabil dibandingkan dengan bank konvensional dengan menggunakan regresi ZSCORE sebagai fungsi dari sejumlah variabel pediktor. Mengikuti Rashid, Yousaf and Khaleequzzaman (2017), model empiris dasar digunakan sebagai berikut:

$$
\begin{aligned}
Z_{i t}= & \beta_{0}+\beta_{1} \text { Profit }_{i t}+\beta_{2} \text { BOPO }_{i t}+\beta_{3} H_{u A s_{i t}}+\beta_{4} \text { Indiv }_{i t}+\beta_{5} \text { LogA }_{i t}+\beta_{6} I N F_{t}+ \\
& \beta_{7} G D P_{t}+\beta_{8} \text { Gov }_{t}+D_{t}+\operatorname{re}_{i}+\varepsilon_{i t}
\end{aligned}
$$

di mana fitur $i$ adalah indeks bank dan $t$ adalah indeks waktu dari data tahunan yang dikumpulkan. Variabel dependen diwakili oleh ZSCORE; Profit adalah indikator rasio profitabilitas; BOPO adalah rasio biaya terhadap pendapatan; Indiv adalah struktur pendapatan; HuAs adalah rasio pinjaman terhadap aset; LogA adalah ukuran aset bank, logaritma natural dari total aset; INF (variabel kontrol) adalah inflasi, yang didefinisikan sebagai perbedaan pertama CPI log (indeks harga pelanggan); GDP (variabel kontrol) adalah tingkat pertumbuhan yang disesuaikan dengan inflasi; Gov (variabel kontrol) adalah indeks tata kelola, diukur dengan merata-rata enam kategori, yaitu: suara dan akuntabilitas, efektivitas tata kelola, peran hukum, stabilitas politik, kualitas regulasi dan kontrol korupsi (Kaufmann, Kraay and Mastruzzi, 2007; Čihák and Hesse, 2010); D adalah Dummy, 0 untuk bank konvensional; 1 untuk bank syariah; re adalah karakteristik bank tertentu, dan $\varepsilon_{\text {it }}$ adalah error. 
Tabel 1 Deskripsi dan Pengukuran Variabel

\begin{tabular}{|c|c|c|c|}
\hline Variabel & Deskripsi & Pengukuran & Interpretasi \\
\hline ZSCORE & Risiko insolvabilitas & $Z_{-}$score $=\frac{\frac{E Q}{A}+\mu_{R O A}}{\sigma_{R O A}}$ & $\begin{array}{lr}\text { Semakin } & \text { tinggi } \\
\text { ZSCORE, semakin } \\
\text { rendah insolvabilitas }\end{array}$ \\
\hline $\begin{array}{l}\text { Struktur } \\
\text { pendapatan } \\
\text { (Indiv) }\end{array}$ & $\begin{array}{lr}\text { Rasio } & \text { ini } \\
\text { menggambarkan } & \\
\text { keberagaman } & \\
\text { pendapatan } & \text { bank. } \\
\text { Untuk bank } & \text { Syariah, } \\
\text { pendapatan bunga } \\
\text { mengacu } & \text { pada } \\
\text { pendapatan bagi hasil } \\
\end{array}$ & $\begin{array}{l}1-\left|\frac{\text { (Pendapatan bunga bersih }- \text { Pendapatan operasi lain })}{\text { Total pendapatan operasi }}\right| \\
\text { Dikalkulasi menurut penelitian Cihak dan Hesse } \\
\text { (2010) dan Rashid, Yousaf, dan } \\
\text { Khaleequzzaman (2017). }\end{array}$ & $\begin{array}{l}\text { Semakin tinggi rasio } \\
\text { struktur pendapatan } \\
\text { semakin rendah } \\
\text { insolvabilitas } \\
\text { (ZSCORE tinggi) }\end{array}$ \\
\hline ROA/ROE & $\begin{array}{lr}\text { Rasio } & \text { profitabilitas } \\
\text { menilai } & \text { kemampuan } \\
\text { bank } & \text { untuk } \\
\text { menghasilkan profit } \\
\text { dan seberapa banyak } \\
\text { earning yang dihasilkan } \\
\text { dengan sumber daya } \\
\text { yang ada } \\
\end{array}$ & $R O E=\frac{\text { Laba setelah pajak }}{\text { Rata }- \text { rata ekuitas }}$ & $\begin{array}{l}\text { Semakin tinggi rasio } \\
\text { profitabilitas, } \\
\text { semakin rendah } \\
\text { insolvabilitas } \\
\text { (ZSCORE tinggi) }\end{array}$ \\
\hline BOPO & $\begin{array}{ll}\text { Rasio efisiensi biaya } \\
\text { menggambarkan } \\
\text { banyaknya biaya yang } \\
\text { dikeluarkan } \\
\text { menghasilkan } \\
\text { pendapatan }\end{array}$ & BOPO $=\frac{\text { Total beban operasional }}{\text { Total pendapatan operasional }}$ & $\begin{array}{l}\text { Semakin tinggi } \\
\text { BOPO, semakin } \\
\text { tinggi insolvabilitas } \\
\text { (ZSCORE rendah) }\end{array}$ \\
\hline HuAs & $\begin{array}{l}\text { Rasio komposisi aset } \\
\text { menggambarkan porsi } \\
\text { aset yang didanai } \\
\text { melalui hutang }\end{array}$ & HuAs $=\frac{\text { Hutang bersih }}{\text { Total aset }}$ & $\begin{array}{l}\text { Semakin tinggi rasio } \\
\text { likuiditas, semakin } \\
\text { tinggi insolvabilitas } \\
\text { (ZSCORE rendah) }\end{array}$ \\
\hline $\log A$ & $\begin{array}{l}\text { Ukuran } \quad \text { bank } \\
\text { merupakan faktor } \\
\text { penting dari kinerja dan } \\
\text { stabilitas bank }\end{array}$ & $\log A=\log$ total aset bank & $\begin{array}{l}\text { Semakin besar aset } \\
\text { bank, semakin } \\
\text { rendah insolvabilitas } \\
\text { (ZSCORE tinggi) }\end{array}$ \\
\hline Inflasi & $\begin{array}{l}\text { Inflasi adalah rate } \\
\text { dimana barang dan jasa } \\
\text { mengalami peningkatan } \\
\text { harga }\end{array}$ & $\begin{array}{l}\text { Perubahan year on year (yoy) dari indeks CPI } \\
\text { (persentase) }\end{array}$ & $\begin{array}{lr}\text { Semakin } & \text { tinggi } \\
\text { inflasi, semakin } \\
\text { tinggi insolvabilitas } \\
\text { (ZSCORE rendah) }\end{array}$ \\
\hline GDP & $\begin{array}{l}\text { GDP adalah ukuran } \\
\text { moneter semua jasa dan } \\
\text { barang akhir yang } \\
\text { diproduksi }\end{array}$ & $\begin{array}{l}\text { Tarif pertumbuhan nominal GDP yang } \\
\text { disesuaikan dengan inflasi (mata uang lokal) }\end{array}$ & $\begin{array}{lr}\text { Semakin } & \text { tinggi } \\
\text { GDP, semakin } \\
\text { rendah insolvabilitas } \\
\text { (ZSCORE tinggi) }\end{array}$ \\
\hline Governance & $\begin{array}{l}\text { Governance adalah } \\
\text { rata-rata ukuran } 6 \\
\text { ukuran governance } \\
\text { yaitu voice and } \\
\text { accountability, political } \\
\text { stability, government } \\
\text { effectiveness, } \\
\text { regulatory quality, rule } \\
\text { of law, dan control of } \\
\text { corruption periode } \\
\text { 2013-2016 menjadi } \\
\text { indeks tunggal per } \\
\text { negara } \\
\text { (GWIdataset.xlxs) }\end{array}$ & $\begin{array}{l}\text { Dikalkulasi menurutz penelitian Cihak dan } \\
\text { Hesse (2010) dan Kaufmann, Kraay, } \\
\text { \&Mastruzzi (2010). }\end{array}$ & $\begin{array}{l}\text { Semakin tinggi } \\
\text { governance, } \\
\text { semakin rendah } \\
\text { insolvabilitas } \\
\text { (ZSCORE tinggi) }\end{array}$ \\
\hline $\begin{array}{l}\text { Dummy } \\
\text { bank syariah }\end{array}$ & $\begin{array}{l}1 \text { bank syariah; } 0 \text { bank } \\
\text { konvensional }\end{array}$ & $\begin{array}{l}\text { Interaksi antara variabel dummy bank syariah } \\
\text { dengan variabel independen }\end{array}$ & $\begin{array}{lr}\text { Diharapkan } & \text { variabel } \\
\text { interaksi } & \text { dengan }\end{array}$ \\
\hline $\begin{array}{l}\text { Dummy } \\
\text { bank } \\
\text { konvensional }\end{array}$ & $\begin{array}{l}1 \text { bank konvensional; } 0 \\
\text { bank syariah }\end{array}$ & $\begin{array}{lccc}\text { Interaksi } & \text { antara } & \text { variabel dummy } & \text { bank } \\
\text { konvensional dengan variabel independen } & \end{array}$ & $\begin{array}{l}\text { dummy } 1 \\
\text { berpengaruh pada } \\
\text { risiko insovabilitas }\end{array}$ \\
\hline
\end{tabular}


Setelah memperkirakan model dasar, model selanjutnya dibangun untuk menguji efek diferensial dari faktor-faktor penentu stabilitas keuangan pada perbankan Islam dan bank konvensional. Model tersebut adalah sebagai berikut:

$$
\begin{aligned}
Z_{i t}= & \beta_{0}+\beta_{1} \text { Profit }_{i t} * D^{B K}+\beta_{2} \text { Profit }_{i t} * D^{B S}+\beta_{3} B O P O_{i t} * D^{B K}+\beta_{4} B O P O_{i t} * D^{B S}+ \\
& \beta_{5} \text { HuAs }_{i t} * D^{B K}+\beta_{6} H u A s_{i t} * D^{B S}+\beta_{7} \text { Indiv }_{i t} * D^{B K}+\beta_{8} \text { Indiv }_{i t} * D^{B S}+\beta_{9} \text { Log }_{i t} * \\
& D^{B K}+\beta_{10} \log _{i t} * D^{B S}+\beta_{11} I N F_{t} * D^{B K}+\beta_{12} I N F_{t} * D^{B S}+\beta_{13} G D P_{t} * D^{B K}+ \\
& \beta_{14} G D P_{t} * D^{B S}+\beta_{15} \text { Gov }_{i t} * D^{B K}+\beta_{16} \text { Gov }_{t} * D^{B S}+\operatorname{re}_{i}+\varepsilon_{i t} \quad \text { Persamaan (3) }
\end{aligned}
$$

di mana $\mathrm{D}^{B K}$ adalah variabel dummy untuk bank konvensional, 1 bank konvensional dan 0 bank syariah dan $\mathrm{D}^{B S}$ adalah variabel dummy untuk bank Syariah, 1 bank Syariah dan 0 bank konvensional. Definisi variabel lain sama seperti di persamaan sebelumnya. Kerangka kerja ini memungkinkan penulis untuk menguji dampak diferensial langsung dari masing-masing variabel yang mendasari stabilitas keuangan di kedua jenis bank.

Studi ini menggunakan dua persamaan dengan spesifikasi berbeda untuk melihat konsistensi hasil tes sebagaimana digunakan oleh Rashid, Yousaf and Khaleequzzaman (2017). Model 1 menginput semua variabel karakteristik khusus bank ke persamaan regresi. Model 2 menambah variabel kontrol berupa makro ekonomi dan tata kelola.

\section{HASIL PENELITIAN DAN PEMBAHASAN}

\subsection{Kalkulasi ZSCORE}

Analisis dimulai dengan melakukan uji statistik awal atas ZSCORE masing-masing sampel. Pairwise comparisons dilakukan untuk ZSCORE bank syariah dan bank konvensional. Tabel 2 adalah statistik deskriptif stabilitas keuangan kedua kelompok bank, syariah dan konvensional. Nilai rata-rata ZSCORE yang rendah mengindikasikan stabilitas bank lebih rendah. Dapat dilihat nilai rata-rata ZSCORE bank konvensional lebih tinggi dari nilai rata-rata bank syariah. Artinya, secara umum stabilitas keuangan bank konvensional lebih tinggi dari stabilitas keuangan bank syariah. Hasil ini berbeda dengan penelitian yang dilakukan oleh Čihák and Hesse (2010), Shahid and Abbas (2012), Rashid, Yousaf and Khaleequzzaman (2017).

Tabel 2. Statistik Deskriptif ZSCORE

\begin{tabular}{lrrr}
\hline \multicolumn{1}{c}{ Variabel } & \multicolumn{1}{c}{ Semua Bank } & \multicolumn{1}{c}{ Bank Syariah } & Bank Konvensional \\
\hline Observasi & 196 & 40 & 156 \\
Mean & .690024 & .480935 & .743637 \\
Minimum & -.1693 & -.1693 & .2633 \\
Maximum & 1.9036 & 1.9036 & 1.0783 \\
Std. Deviation & .4102971 & .7010115 & .2719656 \\
\hline
\end{tabular}

\subsection{Hasil Regresi}

Setelah memenuhi uji asumsi klasik dan tidak ada masalah dengan normalitas (uji Kolmogorov-Smirnov, Asymp. Sig. (2-tailed) .078>0.05), multikolinearitas (angka tolerance > .10 dan VIF < 10), autokorelasi (uji Durbin-Watson sebesar .921 , berada di area bebas autokorelasi), dan heteroskedastisitas (uji Spearman's Rho, nilai signifikansi semua variabel bebas > .05), uji hipotesis sebagaimana dijelaskan dalam metodologi penelitian dilakukan dan hasilnya dapat dilihat pada Tabel 3 dan Tabel 4. 
Koefisien determinasi regresi pada Model 1 adalah .142, mengindikasikan bahwa model ini mampu menjelaskan pengaruhnya sebesar $14.2 \%$. Saat variabel makro ekonomi dan tata kelola dimasukkan dalam persamaan (Model 2), pengaruh itu meningkat menjadi .271 (27.1\%). Hal yang sama juga terjadi saat diterapkan pada persamaan (3). Ini mengindikasikan bahwa indikator makro ekonomi dan tata kelola mampu menjelaskan perubahan variabel stabilitas keuangan (Čihák and Hesse, 2010; Rashid, Yousaf and Khaleequzzaman, 2017).

Pada Model 1, hasil variabel profitabilitas adalah positif dan signifikan. Artinya, bank dengan profitabilitas tinggi lebih stabil dibandingkan bank dengan profitabilitas rendah. Temuan ini juga mengilustrasikan bahwa semakin tinggi profitabilitas semakin rendah risiko insolvabilitas. Hasil dari variabel dummy mendukung asumsi tersebut, yang ditandai dengan nilai koefisien dummy negatif di mana pairwise comparison kedua bank menunjukkan bahwa nilai ZSCORE bank syariah lebih rendah dibandingkan dengan nilai ZSCORE bank konvensional. Hasil ini konsisten dengan penelitian Rashid, Yousaf, dan Khaleequzzaman (2017).

Tabel 3. Estimasi Stabilitas Keuangan

\begin{tabular}{lll}
\hline & Model 1 & Model 2 \\
\hline Profit & $.000(.098)^{*}$ & $.001(.096)^{*}$ \\
BOPO & $-.006(.032)^{* *}$ & $-.004(.119)$ \\
Indiv & $-.037(.074)^{*}$ & $-.014(.904)$ \\
HuAs & $.546(.242)$ & $.554(.202)$ \\
LogA & $.031(.044)^{* *}$ & $.028(.047)^{* *}$ \\
Dummy & $-.233(.001)^{* * *}$ & $-.239(.000)^{* * *}$ \\
Inf & & $-.207(.043)^{* *}$ \\
GDP & & $.225(.007)^{* * *}$ \\
Gov & $1.348(.005)^{* * *}$ & $-3.483(.003)^{* * *}$ \\
Konstan & .142 & $.478(.312)$ \\
R-square & 196 & .271 \\
Observasi & 196 \\
Catatan: * mengindikasikan signifikan pada level 10\%; ** mengindikasikan signifikan pada level 5\%; *** \\
mengindikasikan signifikan pada level 1\%; dummy 1 bank syariah dan 0 bank konvensional. \\
\hline
\end{tabular}

Koefisien rasio BOPO adalah negatif dan secara statistik signifikan. Hasil ini adalah seperti yang diharapkan, yang mengindikasikan bahwa bank yang memiliki rasio BOPO tinggi cenderung lebih kurang stabil. Temuan ini di dukung oleh penelitian Rashid, Yousaf and Khaleequzzaman (2017) dan Shahid and Abbas (2012). Sebaliknya, rasio likuiditas (HuAs) adalah positif dan tidak signifikan. Hasil ini sejalan dengan temuan Rashid, Yousaf and Khaleequzzaman (2017) yang menyatakan bahwa bank dengan rasio HuAs tinggi lebih stabil, namun kontradiktif dengan studi Čihák and Hesse (2010) yang menyatakan bahwa bank dengan rasio HuAs tinggi kurang stabil.

Hasil regresi ukuran bank terhadap stabilitas keuangan menunjukkan koefisien positif dan signifikan (koefisien $=.031 ; p$-value $=.044$ ), yang bermakna bahwa ukuran bank memiliki hubungan yang positif dengan stabilitas keuangan. Dalam penelitian ini, variabel ukuran perusahaan diwakili oleh logaritma aset bank. Artinya, semakin tinggi aset bank semakin tinggi nilai ZSCORE. Bank dengan nilai ZSCORE tinggi, probabilitas insolvabilitasnya semakin rendah dan secara positif berkontribusi pada sistem stabilitas keuangan. Temuan ini konsisten 
dengan penelitian Čihák and Hesse (2010), Shahid and Abbas (2012), Husein (2014), Rashid, Yousaf and Khaleequzzaman (2017).

Model 2 memasukkan indikator makro ekonomi (inflasi dan GDP) dan variabel tata kelola ke persamaan regresi. Seperti yang diharapkan, keduanya signifikan dan koefisien variabel inflasi negatif (koefisien $=-.239, p$-value $=.043$ ) dan GDP positif (koefisien $=.225, p$-value $=$ .007). Temuan ini mengindikasikan bahwa insolvabilitas bank dipengaruhi oleh inflasi dan tingkat pertumbuhan GDP. Temuan ini konsisten dengan penelitian sebelumnya seperti Čihák and Hesse (2010), Shahid and Abbas (2012), Rashid, Yousaf and Khaleequzzaman (2017). Tidak seperti yang diharapkan, variabel governance memiliki koefisien negatif. Temuan ini tidak didukung oleh penelitian sebelumnya yaitu Čihák and Hesse (2010).

\subsection{Efek Diferensial Bank Syariah dan Konvensional}

Persamaan (3) digunakan untuk menguji efek diferensial faktor-faktor empiris yang mempengaruhi stabilitas keuangan bank syariah dan bank konvensional. Hasil pengujian disajikan dalam Tabel 4. Mengacu pada penelitian Rashid, Yousaf and Khaleequzzaman (2017), penelitian ini juga menggunakan dua variabel dummy yang diinteraksikan dengan setiap variabel prediktor yang dimasukkan dalam model. Variabel dummy $\left(\mathrm{D}^{B S}\right)$ untuk bank syariah dan variabel dummy $\left(\mathrm{D}^{B K}\right)$ untuk bank konvensional. Ini memungkinkan penulis untuk menguji dampak diferensial dari setiap variabel prediktor. Kerangka konseptual empiris ini digunakan untuk mengestimasi regresi secara terpisah antara bank syariah dengan bank konvensional untuk mengasilkan degree of freedom yang tinggi. Pendekatan ini juga memungkinkan penulis untuk membandingkan secara langsung dampak dari masing-masing variabel penjelas yang mendasari stabilitas keuangan kedua bank (Rashid, Yousaf and Khaleequzzaman, 2017).

Variabel BOPO di kedua model (Tabel 4) menghasilkan tanda koefisien yang positif dan secara statistik signifikan untuk bank konvensional dan negatif dan tidak signifikan untuk bank syariah. Temuan ini konsisten dengan hasil penelitian Rashid, Yousaf and Khaleequzzaman (2017) dan Husein (2014). Alasan yang dimungkinkan untuk menjelaskan situasi ini adalah bank syariah relatif kecil ukurannya dibandingkan dengan bank konvensional yang telah lama mapan dari sisi stabilitas maupun operasinya sehingga ia dapat beroperasi dengan efisien dari segi biaya operasional. Di Indonesia, bank syariah relatif baru, kecil dari segi ukuran sehingga ia beroperasi dengan biaya operasional yang relatif tinggi. Temuan ini konsisten dengan penelitian Rashid, Yousaf and Khaleequzzaman (2017) dan beberapa peneliti lain seperti Čihák and Hesse (2010), Shahid and Abbas (2012), Husein (2014) yang melaporkan bahwa bank konvensional lebih efisien dibandingkan dengan bank syariah.

Variabel lain yang memiliki efek berbeda adalah profitabilitas. Kedua bank memiliki koefisien profitabilitas positif, namun secara statistik signifikan bagi bank syariah (koefisien $=$ $.057, p$-value $=.012$ ) dan tidak signifikan bagi bank konvensional (koefisien $=.007, p$-value $=$ .876) (Model 1). Hasil ini sejalan dengan temuan Rashid, Yousaf, dan Khaleequzzaman (2017). Mereka berpendapat bahwa profitabilitas bagi bank syariah memiliki peran yang penting dalam mendukung stabilitas keuangannya. Variabel ukuran bank (LogA) juga menunjukkan hasil yang berbeda, yaitu negatif signifikan untuk bank konvensional dan negatif tidak signifikan untuk bank syariah. Hasil ini diperkuat oleh spesifikasi Model 2.

Variabel struktur pendapatan (Indiv) juga menunjukkan hasil yang berbeda bagi kedua bank. Koefisien struktur pendapatan bank syariah positif dan signifikan dan negatif tidak 
signifikan untuk bank konvensional. Hasil ini sejalan dengan studi Rashid, Yousaf and Khaleequzzaman (2017) yang mengindikasikan bank syariah dengan tingkat income diversity yang tinggi cenderung memiliki nilai ZSCORE tinggi dan pada akhirnya akan meningkatkan stabilitas keuangannya. Sebaliknya, bank konvensional dengan income diversity tinggi cenderung memiliki nilai ZSCORE rendah sehingga probabilitas insolvabilitas meningkat. Menurut Rashid, Yousaf and Khaleequzzaman (2017), hasil income diversity untuk bank syariah yang demikian adalah masuk akal. Pendapatan bank syariah tidak hanya bergantung pada aktivitas pinjam meminjam, namun bank juga bergantung pada beberapa sumber pendapatan lain yang secara positif berkontribusi pada peningkatan stabilitas keuangan bank syariah.

Rasio likuiditas berpengaruh terhadap stabilitas keuangan di kedua jenis bank kecuali untuk Model 1 bank konvensional. Estimasi koefisien pada bank syariah menunjukkan tanda positif dan signifikan (koefisien $=1.184 ; p$-value $=.014$ ). Artinya, kesehatan bank syariah akan meningkat dengan adanya peningkatan relatif investasi (pinjaman dalam konteks bank non syariah) atas aset bank. Sebaliknya, koefisien pada bank konvensional adalah negatif dan secara statistik tidak signifikan (koefisien $=-.067 ; p$-value $=.919$ ), yang dapat diinterpretasikan bahwa bank dengan rasio likuiditas tinggi cenderung memiliki nilai ZSCORE yang rendah. Probabilitas insolvabilitas yang meningkat seiring dengan peningkatan rasio likuiditas mengindikasikan bahwa bank konvensional mungkin menghadapi risiko lebih terkait aktivitas kreditnya sehingga meningkatkan kemungkinan terjadinya insolvabilitas. Artinya, risiko portofolio bank syariah lebih sedikit dibandingkan dengan risiko portofolio bank konvensional. Hasil ini didukung oleh penelitian Čihák and Hesse (2010), Shahid and Abbas (2012), Rashid, Yousaf and Khaleequzzaman (2017).

Beralih ke pengaruh variabel makro ekonomi, GDP dan inflasi, terhadap stabilitas keuangan, yang juga menunjukkan hasil yang berbeda untuk kedua jenis bank sampel penelitian. Variabel GDP menunjukkan hasil nilai koefisien positif signifikan untuk bank syariah (koefisien $=1.612 ; p$-value $=.000$ ) dan negatif signifikan untuk bank konvensional (koefisien $=-.106 ; p$ value $=.075)$. Hasil ini sejalan dengan penelitian Čihák and Hesse (2010), Shahid and Abbas (2012), Rashid, Yousaf and Khaleequzzaman (2017). Variabel inflasi di kedua bank signifikan namun bank syariah memiliki koefisien negatif (koefisien $=-1.751 ; p$-value $=.000$ ) sementara itu bank konvensional memiliki koefisien positif (koefisien $=.158 ; p$-value $=.033$ ). Hasil ini mengindikasikan bahwa inflasi yang tinggi akan berdampak pada stabilitas keuangan bank konvensional maupun bank syariah. Bagi bank syariah, inflasi yang tinggi akan menurunkan stabilitas keuangannya. Menurut Rashid, Yousaf and Khaleequzzaman (2017), alasan untuk hasil ini dapat dikaitkan dengan karakteristik bank syariah yang menggunakan sistem PLS sehingga fluktuasi inflasi berdampak langsung terhadap kesehatan finansialnya. Sebaliknya, bank konvensional yang menggunakan sistem bunga tetap tidak menyebabkan stabilitas keuangan menurun meskipun ekonomi sedang mengalami inflasi. Temuan ini didukung oleh penelitian Čihák and Hesse (2010), Shahid and Abbas (2012), Rashid, Yousaf and Khaleequzzaman (2017).

Variabel governance ini menunjukkan perbedaan tanda koefisien, negatif untuk bank syariah (koefisien $=-21.978$; p-value $=.000$ ) dan positif untuk bank konvensional (koefisien = .905; p-value =.277). Hasil ini sejalan dengan studi Čihák and Hesse (2010). 
Tabel 4. Efek Diferensial Bank Syariah dan Konvensional

\begin{tabular}{|c|c|c|}
\hline & Model 1 & Model 2 \\
\hline Profit* $D^{B K}$ & $.007(.876)$ & $.051(.064)^{*}$ \\
\hline Profit* $D^{B S}$ & $.057(.012)^{* *}$ & $.012(.081)^{*}$ \\
\hline $\mathrm{BOPO} * \mathrm{D}^{\mathrm{BK}}$ & $.005(.100)^{*}$ & $.001(.075)^{*}$ \\
\hline $\mathrm{BOPO} * \mathrm{D}^{\mathrm{BS}}$ & $-.015(.119)$ & $-.005(172)$ \\
\hline $\operatorname{Indiv}^{*} \mathrm{D}^{\mathrm{BK}}$ & $-.071(.631)$ & $-.053(.550)$ \\
\hline $\operatorname{Indiv}^{*} \mathrm{D}^{\mathrm{BS}}$ & $.354(.027)^{* *}$ & $.061(.075)^{* * *}$ \\
\hline $\mathrm{HuAs} * \mathrm{D}^{\mathrm{BK}}$ & $-.067(.919)$ & $-1.609(.000)^{* * *}$ \\
\hline $\mathrm{HuAs} * \mathrm{D}^{\mathrm{BS}}$ & $1.184(.014)^{* *}$ & $.472(.024)^{* *}$ \\
\hline $\log A * D^{B K}$ & $-.034(.037)^{* *}$ & $-.027(.007) * * *$ \\
\hline $\log A * D^{B S}$ & $-.045(426)$ & $-.24(.486)$ \\
\hline $\operatorname{Inf} * D^{B K}$ & & $.158(.033)^{* *}$ \\
\hline $\operatorname{Inf} * D^{B S}$ & & $-1.751(.000)^{* * *}$ \\
\hline GDP* $D^{\mathrm{BK}}$ & & $-.106(.075)^{*}$ \\
\hline $\mathrm{GDP} * \mathrm{D}^{\mathrm{BS}}$ & & $1.612(.000)^{* * *}$ \\
\hline Gov*D ${ }^{B K}$ & & $.905(.277)$ \\
\hline Gov $* D^{B S}$ & & $-21.978(.000)^{* * *}$ \\
\hline Konstan & $1.726(.005)^{* * *}$ & $-.440(.274)$ \\
\hline R-square & .172 & .711 \\
\hline Observasi & 196 & 196 \\
\hline \multicolumn{3}{|c|}{$\begin{array}{l}\text { Catatan: * mengindikasikan signifikan pada level } 10 \% \text {; } * * \text { mengindikasikan signifikan pada level } 5 \% \text {; } * * \\
\text { mengindikasikan signifikan pada level } 1 \% ; \mathrm{D}^{\mathrm{BK}} \text { adalah dummy konvensional di mana } 1 \text { bank konvensional dan } \\
0 \text { bank syariah; } \mathrm{D}^{\mathrm{BS}} \text { adalah dummy bank syariah di mana } 1 \text { bank syariah dan } 0 \text { bank konvensional. }\end{array}$} \\
\hline
\end{tabular}

\section{SIMPULAN}

Secara umum, temuan penelitian ini menyatakan bahwa terdapat perbedaan yang signifikan antara bank syariah dengan bank konvensional terkait efek dari faktor empiris yang mempengaruhi stabilitas keuangan. Oleh karena itu, kontribusi yang diberikan oleh bank syariah terhadap stabilitas sistem keuangan nasional juga berbeda dari bank konvensional. Perbedaan itu terjadi karena sistem operasional kedua bank adalah berbeda. Bank syariah menjalankan aktivitas pendanaan dan investasinya mengikuti aturan syariah dan bank konvensional menjalankan kebijakan sistem bunga tetap (fixed rate) dari kegiatan pinjaman dan investasi. Oleh sebab itu, kedua bank tersebut tidak bisa secara penuh mengkapitalisasi manfaat dari karakteristik khusus masing-masing jenis bank, khususnya yang terkait dengan kesehatan keuangan. Secara umum, penelitian ini menyimpulkan bahwa kontribusi bank konvensional terhadap stabilitas sistem keuangan lebih mendalam ketimbang kontribusi bank syariah.

Temuan dari penelitian ini berguna bukan hanya bagi manajemen bank namun juga bagi investor, nasabah bank, dan pembuat kebijakan. Secara khusus hasil studi berguna dalam membantu meningkatkan pemahaman kami mengenai bagaimana variabel karakteristik bank dan indikator makro ekonomi berhubungan dengan stabilitas keuangan sistem perbankan. Hasil penelitian juga memperdalam pengetahuan terkait dengan peran bank syariah dan konvensional bagi stabilitas keuangan. 
Penelitian selanjutnya dapat menggunakan variasi model dengan spesifikasi yang berbeda. Selain itu, pelibatan cakupan data yang lebih lama juga akan menghasilkan tingkat akurasi hasil yang lebih baik. Penggunaan estimator yang berbeda akan menghasilkan temuan yang lebih kuat.

\section{UCAPAN TERIMA KASIH}

Penulis mengucapkan kepada Fakultas Ekonomi dan Bisnis, Universitas Tanjungpura atas dukungan finansial terhadap penelitian ini.

\section{DAFTAR PUSTAKA}

Ahmed, A. (2010). Global financial crisis: an Islamic finance perspective, International Journal of Islamic and Middle Eastern Finance and Management, 3(4), pp. 306-320. doi: 10.1108/17538391011093252.

Beck, T., Demirgüç-Kunt, A. and Merrouche, O. (2010). Islamic vs. Conventional Banking: Business Model, Efficiency and Stability, World Bank Policy Research Working Paper No. 5446.

Čihák, M. and Hesse, H. (2010). Islamic Banks and Financial Stability: An Empirical Analysis, Journal of Financial Services Research, 38, pp. 95-113. doi: 10.1007/s10693-010-00890 .

Farooq, M. and Zaheer, S. (2015). Are Islamic Banks More Resilient during Financial Panics?, IMF Working Paper WP/15/41.

Ghassan, H. B. and Krichene, N. (2017). Financial Stability of Conventional and Islamic Banks: A Survey, Munich Personal RePEc Archive, (82372), pp. 1-31. Available at: https://mpra.ub.uni-muenchen.de/82372/.

Ghassan, H., Fachin, S. and Guendouz, A. (2013). Financial Stability of Islamic and Conventional Banks in Saudi Arabia: a Time Series Analysis.

Goaied, M. and Sassi, S. (2011) 'Financial Development, Islamic Banking and Economic Growth: Evidence from MENA Region, International Journal of Business and Management Science, 4(2), pp. 105-128.

Husein, M. (2014). The Stability of Islamic banks in Indonesia, in 2nd IBEA-International Conference on Business, Economics, and Accounting. Hong Kong.

Ivičić, L., Kunovac, D., \& Ljuba, I. (2008). Measuring Bank Insolvency Risk in CEE Countries, The Fourteenth Dubrovnik Economic Conference, pp. 1-22.

Kaufmann, D., Kraay, A. and Mastruzzi, M. (2007). The Worldwide Governance Indicators Project : Answering The Critics, (February). doi: 10.1596/1813-9450-4149.

Odeduntan, A. K., Adewale, A. A. and Hamisu, S. (2016). Financial Stability of Islamic Banks: Empirical Evidence, Journal of Islamic Banking and Finance, 4(1), pp. 39-46. doi: 10.15640/jibf.v4n1a5.

OJK (2017). Statistik Perbankan Syariah - Desember 2017. Available at: https://www.ojk.go.id/id/kanal/syariah/data-dan-statistik/statistik-perbankansyariah/Documents/Pages/Statistik-Perbankan-Syariah---Desember-2017/SPS Desember 2017.pdf.

Rahim, S. R. M. and Zakaria, R. H. (2013). Comparison on Stability Between Islamic and Conventional Banks in Malaysia, Journal of Islamic Economics, Banking and Finance. Islami Bank Training and Research Academy, 9(3), pp. 131-149. Available at: https://books.google.co.id/books?id=1Pg9ngAACAAJ.

Rajhi, W. and Hassairi, S. A. (2013). Islamic Banks and Financial Stability: a Comparative Empirical Analysis Between, Région et Développement, (37), pp. 150-176.

Rashid, A., Yousaf, S. and Khaleequzzaman, M. (2017). Does Islamic banking really strengthen 
financial stability? Empirical evidence from Pakistan, International Journal of Islamic and Middle Eastern Finance and Management, 10(2), pp. 130-148. doi: 10.1108/mf.2008.00934jaa.001.

Rokhim, R. and Gamaginta (2011). The Stability Comparison between Islamic Banks and Conventional Banks : Evidence in Indonesia, Paper Presented at the proceedings of the 8th international conference on Islamic economics and finance, 19-21 December, Doha, Qatar, pp. 1-29.

Shahid, M. A. (2012). Financial stability of Islamic banking in Pakistan: An empirical study, African Journal of Business Management, 6(10), pp. 3706-3714. doi: 10.5897/ajbm11.1306.

Sundararajan, V. and Errico, L. (2002). IFIS Products in the Global Financial System Key Issues in Risk Management.pdf. WP/02/192.

Uhde, A. and Heimeshoff, U. (2009). Consolidation in Banking and Financial Stability in Europe', Journal of Banking and Finance, 33(7), pp. 1299-1311. 